\title{
Beetles (Coleoptera) of the Rogów region. Part II - ladybirds (Coccinellidae)
}

\author{
Jerzy Borowski* \\ Department of Forest Protection and Ecology, Warsaw University of Life Sciences, SGGW, \\ ul. Nowoursynowska 159/34, 02-776 Warsaw, Poland \\ *E-mail address: jerzy_borowski@sggw.pl
}

\begin{abstract}
In the present, the second part of the series titled "Beetles (Coleoptera) of the Rogów region" presents a family of ladybirds (Coccinellidae), as one of the better-known families of beetles occurring in the Rogów area. The faunistic data of presented species enriched by bionomical informations. In addition, the study showed a new species of ladybird for the Polish fauna and it is Nephus (B.) bisignatus (Boh.).
\end{abstract}

Keywords: Insecta; Coleoptera; Coccinellidae; Rogów region; faunistic data; bionomy

\section{INTRODUCTION}

Until now from the Rogów region has been reported 29 species of ladybirds (Borowski 2001, Rutkiewicz \& al. 2013). In terms of number of species of beetles individual families occurring in the Rogów region, ladybirds family has occupied 7th place. This condition is undoubtedly the work of M. Nunberg (1986), in which it has 26 species of ladybirds. Of this group, only three species were previously reported (Wiąckowski 1957, Szujecki \& Zaborowski, 1968). Two more species were reported in 1999, from the "Zimna Woda" reserve (Borowski \& Kieszek 1999), located in the "Zimna Woda and Wilczy Dół" range. The last one shown Rutkiewicz \& al. (2013).

The following is a list of the species of ladybirds that occur in the Rogów region. Almost all species have been collected by the author, and a small part of specimens comes from the collection of M. Nunberg, and A. Szujecki. Specimens of evidence are in the collection of Department of Forest Protection and Ecology in Rogów. Names are taken from the Catalogue of Palearctic Coleoptera (Löbl, Smetana 2007). All species have been identified by the author of the work, and most of the determined specimens was verified by Andrzej Jadwiszczak.

\section{RESULTS - REVIEW OF THE SPECIES}

\subsection{Subcoccinella vigintiquatuorpunctata (Linnaeus, 1758)}

For the first time in the Rogów region shown by Szujecki and Zaborowski (1968) and next by Nunberg (1986) and Rutkiewicz \& al. (2013). Common species, caught from late spring to autumn in variety of environments. Most, however, it can be found on dry meadows, wastelands and among ruderal vegetation. 


\subsection{Coccidula rufa (Herbst, 1783)}

- Rogów, „Górki” range, UTM: DC24, 25.VI.1997, 6 exx., field peatbog;

- Gutkowice, UTM: DC33, 29.IV.2001, 1 ex., wet meadow.

Because to the limited number of communities around the waterfronts in the Rogów region, this species of ladybird is quite rare.

\subsection{Coccidula scutellata (Herbst, 1783)}

- Rogów, „Zimna Woda and Wilczy Dół” range, UTM: DC24, 06.VI.1997, 1 ex., forest edge;

- Rogów, UTM: DC24, 06.XI.1998, 1 ex., dead branch of lime, near pond;

- Rogów, UTM: DC24, 29.III.2000, 2 exx., wintering in Typha latifolia stalk;

- Głuchów, UTM: DC33, 30.V.2004, 2 exx. and 31.V.2004, 2 exx., pond edge. In the Rogów region not numerous species, related to water enviroments.

\subsection{Rhyzobius chrysomeloides (Herbst, 1792)}

- Rogów, UTM: DC24, 28.X.1995, 1 ex., under bark, old living pine;

- Rogów, „Zimna Woda and Wilczy Dół” range, UTM: DC24, 20.IX.1997, 1 ex., Moericke’ trap, under pines;

- Rogów, dendrological garden, UTM: DC24, 20.III.1999, 3 exx., under bark, old live Scots pine.

In summer, rarely collected species, because the whole development goes high in the crowns of well-exposed, old pines. The species collected in the wintering period, in the bark of living trees, especially at their base. Specimens are usually found singly, often in the company of Harmonia quadripunctata (Pont.) and Myrrha octodecimguttata (L.).

\subsection{Rhizobius litura (Fabricius, 1787)}

- Rogów, „Doliska” range, UTM: DC24, 06.VI.1995, 1 ex., on herbs;

- Rogów, „Górki” range, UTM: DC24, 07.X.1995, 2 exx., agricultural field, heap of straw;

- Głuchów, UTM: DC33, 31.V.2004, 2 exx., pond edge.

This species has been observed in spring and summer near water. On the wintering, like many other ladybirds, moves into dry places. Hundreds of wintering individuals the author was observed on a dry meadow of southern exposure, where they wintered in the prism finely chopped straw and bran.

\subsection{Scymnus (Parapullus) abietis (Paykull, 1798)}

- Rogów, dendrological garden, UTM: DC24, 21.VI.1996, 1 ex., on herbs; 04.VII.1996, 1 ex., on Picea orientalis; 02.VIII.1996, 2 exx. on spruce; 18.VI.1997, 1 ex., on spruce; 29.VI.1998, 1 ex., on spruce; 04.VII.1998, 1 ex., Moericke trap; 11.VII.1998, 1 ex. on Picea asperata; 17.VII.1998, 1 ex., on spruce.

For the first time in the Rogów region shown by Nunberg (1986). A summer species associated with aphids of the Adelgidae family which living on spruces. 


\subsection{Scymnus (Neopullus) ater Kugelann, 1794}

- Rogów, „Zimna Woda and Wilczy Dół” range, UTM: DC24, 18.IX.1998, 2 exx., old oak, on trunk; 12.VI.1999, 1 ex., on Quercus sp.

Rare species in the Rogów region. That ladybird occurs almost exclusively on oaks, especially old and sunny. Probably it developes in the treetops. Species most easily seen in the warm autumn days when walking down the heated trunk to the wintering.

\subsection{Scymnus (Neopullus) haemorrhoidalis Herbst, 1797}

- Rogów, dendrological garden, UTM: DC24, 17.X.1998, 1 ex., Malaise' trap; 22.VIII.2003, 2 exx., on herbs;

- Rogów, „Górki” range, UTM: DC24, 10.VI.1999, 2 exx., Moericke trap.

For the first time in the Rogów region shown by Nunberg (1986). Species collected in variety of environments, but mainly in deciduous forests.

\subsection{Scymnus (Pullus) auritus Thunberg, 1795}

- Rogów, dendrological garden, UTM: DC24, 30.VIII.1995, 1 ex., Moericke trap; 03.VI.1997, 1 ex., on Scots pine; 06.X.1997, 2 exx., on hornbeam;

- Rogów, „Zimna Woda and Wilczy Dół” range, UTM: DC24, 01.X.1997, 3 exx., on hazel;

- Gutkowice, UTM: DC33, 26.V.1997, 1ex., on oak; 06.VI.1997, 1 ex., on shrub.

For the first time in the Rogów region shown by Nunberg (1986) and next by Byk \& al. (2013). One of the most frequently ladybird caught in the Rogów region. Collecting from the spring to autumn, on various deciduous shrubs and trees, especially oaks.

\subsection{Scymnus (Pullus) ferrugatus (Moll, 1785)}

- Gutkowice, UTM: DC33, 01.X.1997, 1ex., in alder forest, on shrub; 23.IV.1998, 6 exx., on black cherry; 12.X.1998, 1 ex., in alder forest, on shrub.

Collected in spring and autumn in wet places. All specimens in the collection come from an alder forest which occurs along the Rawka river. Especially often collected from black cherry, in a flower time and on leaf hops covered with honeydew.

\subsection{Scymnus (Pullus) impexus Mulsnat, 1850}

- Rogów, dendrological garden, UTM: DC24, 28.IX.1997, 1 ex., on herbs under firs; 11.VII.1998, 1 ex., and 17.VII.1998, 2 exx., on fir; 26.IX.2000, 1 ex., and 19.IX.2001, 1 ex., on Abies concolor.

Species collected in July and September. This ladybird is almost exclusively associated with fires and aphids of the genus Dreyfusia Börner (Adelgidae).

\subsection{Scymnus (Pullus) suturalis Thunberg, 1795}

For the first time in the Rogów region shown by Nunberg (1986). Very common in the Rogów region. Observed in all environments where there are pine trees, with which it is biologically related. The easiest way to catch this species during wintering. Insects overwinter in bark cracks live, old pines, often in large numbers. 


\subsection{Scymnus (Scymnus) frontalis (Fabricius, 1787)}

- Rogów, UTM: DC24, 08.VI.1954, 1 ex., on the wall of swimming pool, leg. A. Szujecki; 2.VI.2003, 1 ex., railway slope; 27-28.V.2007, 2 exx., on the wall of building; 8.VII.2009, 1 ex., on the wall of building; 10.VIII.2010, 1 ex., in the garden;

- Gutkowice, UTM: DC33, 23.V.2000, 1ex., Moericke trap; 14.IV.2004, dune, sandy fossa; 3.VI.2004, 1 ex., xerothermic meadow; 7.IV.2005, 1 ex., dune, sandy fossa; 10.V.2009, 1 ex., xerothermic meadow.

Moderately common species, collected mainly in dry and strongly heated places.

\subsection{Scymnus (Scymnus) interruptus (Goeze, 1777)}

- Rogów, UTM: DC24, 29.IV.2000, 1 ex., 13.VI.2006, 1 ex., 30.VI.2007, 1 ex., all specimens on the wall of building.

Very rare in the Rogów region. All specimens were caught in an synanthropic area, on the wall of a residential building.

\subsection{Scymnus (Scymnus) nigrinus Kugelann, 1794}

- Rogów, dendrological garden, UTM: DC24, 04.VII.1996, 1 ex., and 02.VIII.1996, 1 ex., on Picea orientalis; 05.VIII.1996, 1 ex., on Picea engelmannii; 26.VI.1997, 1 ex., on Pinus cembra;

- Gutkowice, UTM: DC33, 26.IX.1997, 1ex., on a young Scots pine.

For the first time in the Rogów region shown by Nunberg (1986). The species is quite common in the Rogów area. It is a forest species associated with aphids of the Adelgidae family which living on pines and spruces.

\subsection{Scymnus (Scymnus) rubromaculatus (Goeze, 1777)}

- Rogów, dendrological garden, UTM: DC24, 30.VIII.1995, 1 ex., on shrub; 02.VIII.1996, 1 ex., on Picea orientalis.

For the first time in the Rogów region shown by Nunberg (1986). Rarely observed, usually prefers shady places with shrubs.

\subsection{Scymnus (Scymnus) schmidti (Fürsch, 1958)}

- Rogów, UTM: DC24, 8-13.VI.2006, 4 exx., 21.VII.2007, 1 ex., all specimens on the wall of building.

Rare species in the Rogów region. All specimens were caught in an synanthropic area, on the wall of a residential building.

\subsection{Scymnus (Scymnus) suffrianioides apetzoides Capra et Fürsch, 1967}

- Krosnowa, UTM: DC24, 08.VIII.2004, 1 ex., burned railway slope.

Extremely rare ladybird. The only specimen (male) collected in August on burned xerothermic slope of nearby railway line. 
2.19. Nephus (Bipunctatus) bipunctatus (Kugelann, 1794)

- Rogów, dendrological garden, UTM: DC24, 1-31.VII.2008, 1 ex., „Fomes” trap.

For the first time in the Rogów region shown by Borowski and Kieszek (1999). The locality in the dendrological garden is the second place in the Rogów region where this very rare species occurs.

2.20. Nephus (Bipunctatus) bisignatus (Boheman, 1850)

- Gutkowice, UTM: DC33, 14-15.IV.2004, 2 exx., and 19.V.2004, 2 exx., dune, sandy fossa; 12.VII.2006, 1 ex., xerothermic meadow.

A psammophilous species usually collected on the coastal dunes. New species to the Polish fauna.

2.21. Nephus (Nephus) redtenbacheri (Mulsant, 1846)

- Rogów, „Górki” range, UTM: DC24, 25.V.2000, 3 exx., xerothermic meadow; 28.VII.2001, 1 ex., forest edge;

- Gutkowice, UTM: DC33, 10.VI.2000, 1 ex., and 14-15.IV.2004, 3 exx., dune, sandy fossa.

Xerothermic species. That ladybird lives close to the ground or on the lowest plants, so the easiest way to catch it in the spring, when the sparse vegetation is still not high.

\subsection{Stethorus (Stethorus) pusillus (Herbst, 1797)}

- Rogów, dendrological garden, UTM: DC24, 1-30.IX.1996, 1 ex., 15.X.1998, 1 ex., 29.X.1998, 1 ex., all specimens in Malaise trap; 15.VI.1999, 1 ex., and 19.VI.1999, 1 ex., on willow;

- Rogów, „Górki” range, UTM: DC24, 28.VI.1999, 1 ex., on oak;

- Rogów, „Zimna Woda and Wilczy Dół” range, UTM: DC24, 20.IX.1997, 1 ex., Moericke trap; 18.IX.1998, 1 ex., on lime.

Common species, especially during the spring and autumn. Easy to find on the underside of the leaves especially willows and limes.

\subsection{Platynaspis luteorubra (Goeze, 1777)}

- Gutkowice, UTM: DC33, 27.VI.1999, 1 ex., and 24.IX.2000, 1 ex., xerothermic meadow; 23.V.2000, 1 ex., Moericke trap;

- Krosnowa, UTM: DC24, 08.VIII.2004, 1 ex., burned railway slope.

Rare and usually individually collected species, ecologically associated with the xerothermic meadows.

\subsection{Chilocorus bipustulatus (Linnaeus, 1758)}

- Rogów, dendrological garden, UTM: DC24, 26.VI.1996, 1 ex., on Picea asperata; 2.X.2001, 1 ex., on herbs; 9.IX.2003, 5 exx., on bilberry;

- Głuchów, UTM: DC33, 31.V.2004, 1 ex., xerothermic meadow.

The species occurs mainly on conifers, most often collected in spring and autumn. 


\subsection{Chilocorus renipustulatus (Scriba, 1791)}

- Rogów, dendrological garden, UTM: DC24, 26.VI.1995, 2 exx., on herbs; 08.IX.1997, 1 ex., on shrub; 28.IX.1997, 1 ex., 03.IV.1998, 1 ex., and 20.IV.1998, 1 ex., all specimens on bilberry;

- Rogów, UTM: DC24, 02.VI.2003, 1 ex., forest edge;

- Lipce, UTM: DC25, 07.XI.1999, 1 ex., on a branch of beech;

- Gutkowice, UTM: DC33, 15.IV.1999, 1 ex., on bilberry.

For the first time in the Rogów region shown by Nunberg (1986). Species more common than Ch. bipustulatus. Found in variety of environments, but mostly collected from the blueberries under conifers.

\subsection{Exochomus quadripustulatus (Linnaeus, 1758)}

- Rogów, dendrological garden, UTM: DC24, 08.XI.1995, 1 ex., sifted; 07.IV.1996, 5 exx., on spruce, pine and douglas.

- Rogów, „Górki” range, UTM: DC24, 30.V.1995, 1 ex., on herbs;

- Gutkowice, UTM: DC33, 22.IX.1997, 1 ex., on heath.

For the first time in the Rogów region shown by Nunberg (1986). Common species most frequently seen in spring and autumn on conifers.

\subsection{Hyperaspis (Hyperaspis) campestris (Linnaeus, 1758)}

- Rogów, UTM: DC24, 04.VI.1952, 1 ex., leg. A. Szujecki, det. R. Bielawski; 28.IV.2002, 1 ex., indoor building; 23.V.2006, 1 ex., no berbs;

- Rogów, dendrological garden, UTM: DC24, 24.VII.1997, 1 ex., and 03.IV.1998, 3 exx., on herbs; 27.IV.2007, 1 ex., on hawthorn's flower;

- Rogów, „Zimna Woda and Wilczy Dół” range, “Zimna Woda” reserve, UTM: DC24, 16.V.1993, 1 ex., Moericke trap;

- Parcela Popień, „Popień” range, „Popień” reserve, UTM: DC23, 20.VI.1995, 1 ex., Moericke trap.

Quite rare, and usually individually collected species. It develops in the upper parts of the trees, especially on sunny oaks.

\subsection{Hyperaspis (Hyperaspis) concolor (Suffrian, 1843)}

- Gutkowice, UTM: DC33, 20.V.2000, 1 ex., alder forest;

- Głuchów, UTM: DC33, 8.VI.2007, 1 ex., on Aegopodium podagraria flower.

Very rare species in the Rogów region. Both specimens were caught in damp and darkened environments.

\subsection{Hyperaspis (Hyperaspis) pseudopustulata Mulsnat, 1853}

- Rogów, UTM: DC24, 24.V.2007, 1 ex., under oak; 26.VIII.2006, 1 ex., on the window, indor building.

Very rare species in the Rogów region. Both specimens were caught near the growing strongly sunny oak. 


\subsection{Hippodamia (Hemisphaerica) tredecimpunctata (Linnaeus, 1758)}

- Głuchów, UTM: DC33, 19.VIII.1997, 1 ex., on Scots pine; 15.IX.1998, 1 ex., and 10.X.1998, 1 ex., pine crop, on Scots pine;

- Gutkowice, UTM: DC33, 04.IX.1997, 1 ex., on Pinus banksiana; 01.X.1997, 2 exx., xerothermic meadow;

- Rogów, „Zimna Woda and Wilczy Dół” range, UTM: DC24, 01.X.1997, 2 exx., pine crop.

For the first time in the Rogów region shown by Nunberg (1986). The species easiest to find in the autumn, when the juveniles specimens are transferred to the wintering grounds in dry areas. Then we can often observe this species in several years pine crops.

\subsection{Hippodamia (Hippodamia) variegata (Goeze, 1777)}

- Gutkowice, UTM: DC33, 25.VII.1997, 2 exx., and 01.X.1997, 1 ex., on xerothermic meadow;

- Głuchów, UTM: DC33, 01.VIII.1998, 1 ex., drainage ditch.

For the first time in the Rogów region shown by Nunberg (1986) and next by Rutkiewicz \& al. (2013). Quite rare, and usually individually collected species. A xerothermic species occurs in the summer and autumn.

\subsection{Aphidecta obliterata (Linnaeus, 1758)}

- Rogów, dendrological garden, UTM: DC24, 8-11.XI.1995, 10 exx., under bark of Thuja sp.

Ladybird during the season is observed individually. Overwinter under the bark most usually in large groups. Biologically associated with the conifers, especially firs.

\subsection{Anisosticta novemdecimpunctata (Linnaeus, 1758)}

- Głuchów, UTM: DC33, 01.VIII.1998, 8 exx., on Phragmites communis;

- Rogów, UTM: DC24, 29.III.2007, 1 ex., wintering in Typha latifolia stalk. reeds.

The species occurs near the water and biologically associated with the aphids living on

\subsection{Tytthaspis sedecimpunctata (Linnaeus, 1761)}

- Rogów, „Zimna Woda and Wilczy Dół” range, UTM: DC24, 18.XI.1995, 2 exx., sifted;

- Gutkowice, UTM: DC33, 26.V.1997, 2 exx., and 25.VII.1997, 1 ex., xerothermic meadow;

- Rogów, „Górki” range, UTM: DC24, 24.VI.1997, 1 ex., forest edge.

For the first time in the Rogów region shown by Nunberg (1986). Quite commonly collected species throughout the Rogów region, but prefers xerothermic meadows and grasslands.

\subsection{Adalia (Adalia) bipunctata (Linnaeus, 1758)}

For the Rogów region shown by Wiąckowski (1957) and next by Nunberg (1986) and Rutkiewicz \& al. (2013). Very common species, caught from an early spring to the winter in variety of environments. 


\subsection{Adalia (Adalia) decempunctata (Linnaeus, 1758)}

For the first time in the Rogów region shown by Nunberg (1986). Very common species, caught from an early spring to the winter in variety of environments.

\subsection{Adalia (Adaliomorpha) conglomerata (Linnaeus, 1758)}

- Rogów, dendrological garden, UTM: DC24, 26.VI.1996, 1 ex., on Picea glauca; 04.VII.1996, 3 exx., and 02.VIII.1996, 1 ex., on Picea orientalis; 05.VIII.1996, 2 exx., on Picea obovata; 26-27.IV.1997, 2 exx., on herbs; 3.IV.1998, 1 ex., on spruce.

For the first time in the Rogów region shown by Nunberg (1986). In the Rogów area rarely collected species, which biologically is associated with spruces and aphids from Adelgidae family living on them.

2.38. Coccinella (Coccinella) magnifica (Redtenbacher, 1843)

- Gutkowice, UTM: DC33, 22.IX.1997, 1 ex., on heath; 26.IX.1997, 2 exx., on young Scots pines; 28.VII.2007, 3 exx., in gravel pit;

- Głuchów, UTM: DC33, 15.IX.1998, 1 ex., on young Scots pines;

- Lipce, UTM: DC25, 15.IX.1998, 1 ex., on young Scots pines.

The species caught usually in the autumn, in dry and sunny places. It is frequent in pine crops together with Coccinella sepetmpunctata and Hippodamia tredecimpunctata.

\subsection{Coccinella (Coccinella) quinquepunctata (Linnaeus, 1758)}

For the first time in the Rogów region shown by Nunberg (1986). Very common species, caught from an early spring to the winter in variety of environments.

\subsection{Coccinella (Coccinella) septempunctata (Linnaeus, 1758)}

For the first time in the Rogów region shown by Nunberg (1986) and next by Byk \& al. (2013) and Rutkiewicz \& al. (2013). Very common species, caught from an early spring to the winter in variety of environments.

2.41. Coccinella (Spilota) undecimpunctata (Linnaeus, 1758)

- Popień, UTM: DC23, 23.VII.2003, 1 ex., in gravel pit.

Halophilous species, very rare in the Rogów region.

\subsection{Coccinula quatuordecimpustulata (Linnaeus, 1758)}

For the first time in the Rogów region shown by Nunberg (1986) and next by Byk \& al. (2013). Very common species, caught from an early spring to the winter in variety of environments.

2.43. Oenopia conglobata (Linnaeus, 1758)

- Rogów, „Zimna Woda and Wilczy Dół” range, UTM: DC24, 18.XI.1995, 6 exx., under bark of Quercus sp.; 
- Rogów, dendrological garden, UTM: DC24, 13.II.1997, 1 ex. under bark of Picea sp.; 20.III.1999, 1 ex., under bark of old Scots pine; 26.VI.1997, 1 ex., on herbs;

- Rogów, „Jasień” range, UTM: DC24, 24.X.1998, under bark of Populus sp.

In the Rogów region commonly collected species, especially in winter, when overwinters under the bark of different species of trees.

\subsection{Oenopia impustulata (Linnaeus, 1767)}

- Głuchów, UTM: DC33, 28.IV.2007, 1 ex., alder forest.

For the first time in the Rogów region shown by Borowski and Kieszek (1999). Since then, many times but always individually found. Biologically related to the crowns of oaks.

\subsection{Harmonia axyridis (Pallas, 1773)}

- Rogów, UTM: DC24, 10.X.2008, 7 exx., on the walls of buildings.

Invasive species. In the Rogów region appeared in 2008 and since that moment is observed in large numbers in various environments.

\subsection{Harmonia quadripunctata (Pontoppidan, 1763)}

- Rogów, dendrological garden, UTM: DC24, 28.X.1995, 10 exx., under bark of old Scots pine.

For the Rogów region shown by Wiąckowski (1957) and Nunberg (1986). Common species living in the tops of the pine trees. Easy to find during wintering, under the bark and bark cracks on the living, older pines, usually together with Myrrha octodecimguttata.

\subsection{Myrrha (Myrrha) octodecimguttata (Linnaeus, 1758)}

- Rogów, dendrological garden, UTM: DC24, 28.X.1995, 1 ex., 02-03.XI.1995, 3 exx., and 16.XI.1995, 1 ex., under bark of old Scots pine;

- Rogów, „Zimna Woda and Wilczy Dół” range, UTM: DC24, 18.XI.1995, 4 exx., under bark of old Scots pine.

For the first time in the Rogów region shown by Nunberg (1986) and next by Rutkiewicz \& al. (2013). Common species living in the tops of the pine trees. Easy to find during wintering, under the bark and bark cracks on the living, older pines, usually together with Harmonia quadripunctata.

\subsection{Sospita vigintiguttata (Linnaeus, 1758)}

- Rogów, dendrological garden, UTM: DC24, 3.IV.1998, 1 ex., on birch;

- Rogów, UTM: DC24, 25.IV.1998, 1 ex., on herbs;

- Gutkowice, UTM: DC33, 22.IX.1997, 1 ex., alder forest;

- Rogów, "Rogów" range, UTM: DC24, 03.V.2005, 1 ex., and 24.IV.2007, 1 ex., shrubs near the water;

- Parcela Popień, „Popień” range, UTM: DC23, 09.V.2006, 1 ex., on shrubs near Rawka river;

- Głuchów, UTM: DC33, 22.IIII.2014, 1 ex., alder forest. 
In the area of Rogów this species of ladybird is rarely seen and individually. It is usually collected in early spring, near the water.

\subsection{Calvia decemguttata (Linnaeus, 1767)}

- Gutkowice, UTM: DC33, 22.V.1997, 1 ex., 04.IX.1997, 6 exx., and 22.IX.1997, 1 ex., all specimens on birch;

- Rogów, dendrological garden, UTM: DC24, 25.IV.1998, 1 ex., on herbs.

For the first time in the Rogów region shown by Nunberg (1986) and next by Rutkiewicz \& al. (2013). In the Rogów region quite commonly occurring species. It lives on variety of deciduous trees clearly preferring birch.

\subsection{Calvia quatuordecimguttata (Linnaeus, 1758)}

- Rogów, dendrological garden, UTM: DC24, 10.X.1995, 1 ex., on herbs; 26.VI.1996, 1 ex., on alder; 2-3.VI.1997, 4 exx., on birch;

- Gutkowice, UTM: DC33, 04.IX.1997, 1 ex., on birch.

For the first time in the Rogów region shown by Nunberg (1986) and next by Rutkiewicz \& al. (2013). In the Rogów region common species. It lives on variety of deciduous trees clearly preferring birch.

\subsection{Propylea quatuordecimpunctata (Linnaeus, 1758)}

For the first time in the Rogów region shown by Nunberg (1986) and next by Byk \& al. (2013) and Rutkiewicz \& al. (2013). Very common species, caught from an early spring to the winter in variety of environments.

\subsection{Myzia oblongoguttata (Linnaeus, 1758)}

- Rogów, UTM: DC24, 15.VII.1998, 1 ex., on herbs;

- Gutkowice, UTM: DC33, 19.VI.2002, 2 exx., on Populus sp.

M. oblongoguttata is a rare species in the Rogów region. Within 20 years of research, only 3 specimens caught that ladybird, all in the summer.

\subsection{Anatis ocellata (Linnaeus, 1758)}

- Rogów, „Zimna Woda and Wilczy Dół” range, UTM: DC24, 10.X.1953, 1 ex., 08.X.1954, 1 ex., 22.X.1958, 1 ex., leg. M. Nunberg, det. R. Bielawski, all specimens on oaks; 18.V.2003, 1 ex., on herbs;

- Gutkowice, UTM: DC33, 04.IX.1997, 2 exx., on birch.

For the first time in the Rogów region shown by Nunberg (1986) and next by Byk \& al. (2013) and Rutkiewicz \& al. (2013). In the Rogów area rarely collected species which lives on variety of deciduous trees.

\subsection{Halyzia sedecimguttata (Linnaeus, 1758)}

- Rogów, „Zimna Woda and Wilczy Dół” range, UTM: DC24, 9.VIII.1954, 1 ex., leg. M. Nunberg, det. R. Bielawski; 
- Lipce, UTM: DC25, 07.XI.1999, 5 exx., on branches of beech;

- Popień, UTM: DC23, 03.VI.2000, 1 ex., on Populus sp.; 18.VI.2000, 1 ex., on elm.

In the Rogów region rarely collected species. It lives on fruiting bodies of Ascomycetes on branches of deciduous trees.

\subsection{Psyllobora (Thea) vigintiduopunctata (Linnaeus, 1758)}

- Rogów, dendrological garden, UTM: DC24, 10.XI.1995, 1 ex., sifted; 25.VI.1997, 1 ex., on herbs;

- Gutkowice, UTM: DC33, 25.VII.1997, 2 exx., and 23.IV.1998, 1 ex., xerothermic meadow;

- Rogów, „Górki” range, UTM: DC24, 24-25.VI.1997, 2 exx., forest egde.

For the first time in the Rogów region shown by Nunberg (1986). This mycetobiontic ladybird in the Rogów area is a quite commonly occurring species.

\subsection{Vibidia duodecimguttata (Poda, 1761)}

For the first time in the Rogów region shown by Rutkiewicz \& al. (2013). 3 specimens (materials lost) of this labybird were collected in „Popień” and „Rogów” ranges.

\section{CONCLUSIONS}

Ladybirds are one of the better-known families of beetles in the Rogów region. There are 56 known species representing approx. $75 \%$ of all species in our country. As for this poor, agricultural region with a relatively small mosaic of natural environments, this result seems to be very high. Studies have shown a new species for the Polish fauna. It is Nephus (B) bisignatus. Given the ecological requirements of some species which are not caught yet from the Rogów area, it is possible to catch a few more species. However, these species are extremely rare in other regions of the our country.

\section{Acknowledgements}

I would like to thank Andrzej Jadwiszczak (Olsztyn, Poland) for the verify of determination most of the species and Prof. Andrzej Szujecki for the material used in this work.

\section{References}

[1] Borowski J. 2001. Chrząszcze (Coleoptera) okolic Rogowa. Cz. I - Wstęp, rys historyczny badań i stan poznania chrząszczy okolic Rogowa. Sylwan, 145(3): 103-109.

[2] Borowski J., Kieszek C. 1999. Ciekawsze chrząszcze (Coleoptera) odłowione w rezerwacie dębowym "Zimna Woda” w Rogowie. Wiadomości entomologiczne, 18(2): 125-126.

[3] Byk A., Borowski J., Mazur S., Mokrzycki T., Rutkiewicz A. 2013. Waloryzacja lasów Leśnego Kompleksu Promocyjnego „Lasy Spalsko-Rogowskie” na podstawie zgrupowań chrząszczy saproksylicznych. Studia i Materiały CEPL w Rogowie, 35(2): 82-128. 
[4] Löbl I., Smetana A. (ed.). 2007. Catalogue of Palearctic Coleoptera. Vol. 5. Stenstrup: Apollo Books, 935 pp.

[5] Nunberg M. 1986. The beetles (Coleoptera) collected on the area of the Forest Experimental Station at Rogów. Annals of Warsaw Agricultural University - SGGWAR, Forestry and Wood Technology, 34: 11-17.

[6] Rutkiewicz A., Borowski J., Byk A., Mokrzycki T. 2013. Waloryzacja lasów Leśnego Kompleksu Promocyjnego „Lasy Spalsko-Rogowskie” na podstawie zgrupowań chrząszczy saproksylicznych powierzchni pni drzew. Studia i Materiały CEPL w Rogowie, 35(2): 129-159.

[7] Szujecki A., Zaborowski S. 1968. Chrząszcze (Coleoptera) występujące późną jesienią w gniazdach zbudowanych przez dziuplaki w skrzynkach lęgowych. Zeszyty Naukowe SGGW, Leśnictwo, 11: 89-103.

[8] Wiąckowski S. 1957b. Entomofauna pniaków sosnowych w zależności od wieku i rozmiaru pniaka. Ekologia Polska, ser. A, 5(3): 13-140. 